\title{
Currency Substitution, Capital Mobility and Functional Forms of Money Demand in Pakistan
}

\section{Yu Hsing*}

\begin{abstract}
The demand for M2 in Pakistan is positively influenced by real $G D P$ and currency appreciation and negatively influenced by the domestic interest rate and the foreign interest rate. These results confirm international capital mobility and currency substitution. The Box-Cox transformation indicates that the log-linear function cannot be rejected while the linear function can be rejected at the 5\% significance level. The log-linear form of the demand for M2 shows a small value of the mean absolute percent error and performs better in the CUSUM and CUSUMSQ tests than the linear form.
\end{abstract}

Keywords: Currency substitution, capital mobility, Box-Cox model, CUSUM and CUSUMSQ tests

JEL Classification: E41

\section{Introduction}

Several seminal works (Tobin, 1958; Chow, 1966; Goldfeld, 1973, 1976; Judd and Scadding, 1982; Gordon, 1984; Friedman, 1988; Laidler, 1990; Goldfeld and Siche1, 1990) have contributed substantially to the understanding of the demand for money. Small and Porter (1989), Hetzel and Mehra (1989), Hafer and Jansen (1991), Mehra (1993, 1997), Duca (2000), Carlson, Hoffman, Keen and Rasche (2000), and others examined the behavior and stability of M2 for the U.S. For example, Mehra (1997) indicated that the demand schedule for M2 shifted leftward during the early 1990 s and that the behavior of M2 has remained relatively stable since 1994, making it useful for the analysis of monetary policy. Duca (2000)

\footnotetext{
* Charles Blackwell Endowed Professor of Economics, Department of General Business, SLU 10813, College of Business, Southeastern Louisiana University, Hammond, Louisiana 70402, USA. E-mail: yhsing@selu.edu
} 
showed that the decline in M2 and the rise in the velocity of M2 in the early 1990s were matched by the increase in bond mutual funds. He suggested that M2 demand can be modeled better if the market for bond mutual funds is also taken into consideration. Sarno, Taylor, and Peel (2003) indicated that the money demand function for the U.S. was stable during 1869-1997 and that there existed a nonlinear relationship that was adjusted toward the long-term equilibrium.

\section{Literature Review}

There are several studies of the demand for money for Pakistan. Bahmani-Oskooee and Malixi (1991) regressed the demand for M1 in Pakistan on the inflation rate, real output, and the real exchange rate, defined as units of the rupee per foreign currency, and reported that in the long-run, depreciation of the rupee caused the demand of money to decrease. Arize (1994) showed that in estimating the money demand function for Pakistan, the error-correction model performed well and that the inclusion of a foreign interest rate or monetary variable would be appropriate due to its influence on money demand. In studying the demand for money for Pakistan and three other Asian countries, Hsing (1998) indicated that the Box-Cox transformation should be employed to test whether the constant elasticity hypothesis may be valid. Khan, Arby, and Lodhi (2000) revealed that currency and demand deposits in Pakistan were extremely sensitive to real income but insensitive to exchange rates and interest rates, while quasi-money was insensitive to real income but sensitive to exchange rates and interest rates. Bahmani-Oskooeea and Rehman (2005) found that the demand for M2 in Pakistan has a positive relationship with real output and the exchange rate, and a negative relationship with the inflation rate and that M2 demand was relatively stable. The positive effect of the exchange rate suggests that the demand for M2 would increase as the rupee depreciates or that the wealth effect dominates the substitution effect. Because the domestic interest rate and the foreign interest rate were not included in the estimated regression, the response of money demand to interest rate changes cannot be measured.

This paper differs from previous studies in several aspects. First, the extended Box-Cox transformation (Box-Cox, 1964; Seaks and Layson, 1983; Greene, 2003) is applied to test whether the log-linear form or the linear form cannot be rejected. Most previous studies chose the log-linear form without a priori knowledge of whether it is appropriate. Second, comparative-static analysis is applied to analyze the importance of the sensitivity of money demand to a change in the interest rate and its potential impacts on fiscal policy and a change in the exchange rate or the 
foreign interest rate on the equilibrium real output. Third, the Newey-West (1987) method is employed to generate consistent estimates for standard errors and covariance when the forms of heteroskedasticity and autocorrelation are unknown.

\section{The Model}

Extending previous studies, the demand for real money balances in Pakistan can be expressed as:

$$
\begin{gathered}
M=L\left(Y, R, E, R^{*}\right), \\
L_{Y}>0, L_{R}<0, L_{E}>\text { or }<0, L_{R}{ }^{*}>\text { or }<0
\end{gathered}
$$

where

$M=$ demand for real money balances,

$\mathrm{Y}=$ real output,

$\mathrm{R}=$ the domestic interest rate,

$\mathrm{E}=$ the real effective exchange rate, and

$\mathrm{R}^{*}=$ the foreign interest rate.

Note that in the money demand function, the conventional approach is to use the nominal interest rate. Because the nominal interest rate is equal to the real interest rate plus the expected inflation rate, the real interest rate is implicitly considered (Romer, 2006, p. 226). In money market equilibrium, it can be shown that the slope of the LM curve is given by:

$$
\left.\frac{d R}{d Y}\right|_{L M}=-\frac{\partial M / \partial Y}{\partial M / \partial R}>0
$$

If $|\partial M / \partial R|$ is very small, or if money demand is very insensitive to an interest rate change, the slope of LM will be very steep, and vice versa. When LM is very steep, any expansionary fiscal policy would be less effective in raising real output. This can be analyzed by the general equilibrium in the goods and money markets. The potential impact of increased government spending on the equilibrium real output can be expressed as: 


$$
\partial \bar{Y} / \partial G=-H_{G} L_{R} /|J|>0
$$

Where $H_{G}$ is the partial derivative of aggregate spending with respect to government spending, $L_{R}$ is the partial derivative of money demand with respect to the interest rate, and $|J|$ is the Jacobian with a positive value. Hence, a small value of $\left|L_{R}\right|$ is expected to reduce the impact of increased government spending on the equilibrium real output.

In a similar manner, the impact of government tax revenue on the equilibrium real output can be written as:

$$
\partial \bar{Y} / \partial T=-H_{T} L_{R} /|J|<0
$$

Where $H_{T}$ is the partial derivative of aggregate spending with respect to government tax revenue. Thus, the effect of a tax cut will be small if the value of $\left|L_{R}\right|$ is small.

The impact of a change in the nominal exchange rate or the foreign interest rate on the equilibrium output can be expressed as:

$$
\begin{aligned}
& \partial \bar{Y} / \partial E=\left(-H_{E} L_{R}+H_{R} L_{E}\right) /|J|>\text { or }<0 \text { if } L_{E}>0 \text { and }>0 \text { if } L_{E}<0 \\
& \partial \bar{Y}\left|\partial R^{*}=H_{R} L_{R}{ }^{*}\right||J|>0 \text { if } L_{R^{*}}<0 \text { and }<0 \text { if } L_{R^{*}}>0
\end{aligned}
$$

where $H$ is aggregate spending and $H_{x}$ is the partial derivative of $H$ with respect to any right-hand side variable $\mathrm{X}$. As shown, the sign of $L_{E}$ and $L_{R^{*}}$ is crucial in determining whether a change in one of the variables would affect the equilibrium real output positively or negatively.

The extended Box-Cox model (Box and Cox, 1964; Seaks and Layson, 1983; Greene, 2003) is employed to transform all the variables with positive values as follows:

$$
\begin{aligned}
& M^{(\lambda)}=\left(M^{\lambda}-1\right) / \lambda \\
& X^{(\lambda)}=\left(X^{\lambda}-1\right) / \lambda
\end{aligned}
$$

where $\mathrm{X}$ is any of the right-hand-side variables and $\lambda$ is the transformation parameter. It can be shown that when $\lambda$ approaches zero, equation (1) reduces to a double-log form, and when $\lambda=1$, equation (1) becomes a linear 
form. The test statistic has a $\chi^{2}$ distribution with one degree of freedom and is given by:

$$
J(\lambda)=2[L(\hat{\lambda})-L(\lambda=0 \text { or } 1)] \sim \chi_{(1)}^{2}
$$

The elasticity of real money demand with respect to any explanatory variable $\mathrm{X}$ at the means is given by:

$$
E_{X}=\beta(\bar{X} / \bar{M})^{\lambda}
$$

where $E_{X}$ is the elasticity of $M$ with respect to any variable $\mathrm{X}$ and $\beta$ is the estimated coefficient for any variable $\mathrm{X}$.

\section{Data and Variables}

All the data were taken from the International Financial Statistics which is published by the International Monetary Fund. Nominal M2 is divided by the CPI to derive real M2 measured in millions. Real GDP is measured in billions at 2000 prices. The call money rate is chosen to represent the domestic interest rate. The real effective exchange rate is used mainly because people are likely to react to a basket of foreign currencies in determining whether they may like to hold more or less foreign currencies. The 3-year U.S. T-bond rate is selected to represent the foreign interest rate.

The sample ranges from 1980 to 2005 because earlier data for the real effective exchange rate are not available. Quarterly data are not used because of lack of quarterly statistics for real GDP.

\section{Empirical Results}

Unit root tests show that all the variables have unit roots in levels and are stationary in first differences. In the $\mathrm{ADF}$ cointegration test, $\Delta U_{t}=\alpha U_{t-1}$ where $U$ is the regression residual, the test statistic of -3.82 is greater than the critical value of -3.41 (in absolute value) at the $5 \%$ level. $\Delta U_{t-1}, \Delta U_{t-2}$, etc. are not included due to the insignificance of the coefficients. Hence, the demand for money and four explanatory variables have a stable long-term relationship.

The functional form is tested. The critical value with a $\chi^{2}$ distribution and 1 degree of freedom is 3.841 and 6.635 at the $5 \%$ and $1 \%$ levels, respectively. As shown in Table-1, the value of $L(\hat{\lambda})$ is -320.171 with 
an estimated $\lambda$ of 0.170 . The value of $L(\lambda=0)$ for the double-log form is 320.218. The test statistic is 0.094 . Hence, the log-linear form cannot be rejected at the $5 \%$ level. The linear form can be rejected because the value of the test statistic of 8.500 is far greater than the critical values at the $5 \%$ or $1 \%$ level.

Table- 1 presents the estimated regression and related statistics for the demand for M2. The paper does not employ the first-difference form because the results would become obscure due to the loss of important information (Greene, 2003). In the Box-Cox mode1, 98.8\% of the variation in the demand for M2 can be explained by the four right-hand side variables. All the coefficients are significant at the $1 \%$ or $5 \%$ level. The demand for M2 is positively associated with real GDP and the real effective exchange rate and negatively influenced by the call money rate and the 3-year U.S. T-bond rate.

Table-1. Estimated Regressions of the Demand for M2 in Pakistan

\begin{tabular}{lccc}
\hline \multicolumn{1}{c}{ Variable Name } & $\begin{array}{c}\text { Box-Cox } \\
\text { Model }\end{array}$ & $\begin{array}{c}\text { Log-linear } \\
\text { Function }\end{array}$ & $\begin{array}{c}\text { Linear } \\
\text { Function }\end{array}$ \\
\hline Real GDP & 4.522 & 1.573 & 716.860 \\
& $(7.722)$ & $(6.630)$ & $(13.614)$ \\
Call money rate & -0.803 & -0.078 & -33178.570 \\
& $(3.562)$ & $(2.202)$ & $(6.510)$ \\
REER & .272 & 0.636 & 6964.399 \\
& $(3.365)$ & $(2.604)$ & $(6.170)$ \\
U.S. T-Bond Rate & -1.296 & -0.178 & -24400.900 \\
& $(2.169)$ & $(2.518)$ & $(2.266)$ \\
Intercept & -39.413 & -1.206 & -141204.000 \\
& $(2.296)$ & $(0.396)$ & $(4.945)$ \\
$\mathrm{R}^{2}$ & 0.988 & 0.987 & 0.987 \\
D-W & 1.345 & 1.290 & 1.414 \\
$\lambda$ & 0.170 & 0.000 & 1.000 \\
$L(\lambda)$ & -320.171 & -320.218 & -324.421 \\
$J(\lambda)$ & & 0.094 & 8.500 \\
MAPE & 4.248 & 4.282 & 5.639 \\
\hline
\end{tabular}

Notes:

$\lambda$ is the Box-Cox transformation parameter.

$L(\lambda)$ is the log-likelihood function.

$J(\lambda)$ is the value of the test statistic.

MAPE is the mean absolute percent error. 
In the log-linear function, $98.7 \%$ of the variation in the demand for M2 can be explained by the four explanatory variables. All the coefficients are significant at the $1 \%$ or $5 \%$ level. The demand for M2 has a positive relationship with real output and the real effective exchange rate and a negative relationship with the call money rate and the foreign interest rate. The log-linear form has smaller mean absolute percent error than the linear form.

The positive sign of the real effective exchange rate shows that appreciation of the rupee leads to an increase in the demand for money and implies that the substitution effect is greater than the wealth effect (Arango and Nadiri, 1981; McKinnon, 1982; Bahmani-Oskooee and Techaratanachai, 2001; Bahmani-Oskooee and $\mathrm{Ng}, 2002$ ). The negative sign of the U.S. Tbond rate suggests that the capital mobility effect is greater than the cost of borrowing effect (Marquez, 1987; Bahmani-Oskooee and Ng, 2002).

The CUSUM and CUSUMSQ tests in Figure 1 show that in the loglinear form, the demand for M2 for Pakistan is relatively stable as most of the cumulative sum of the recursive residuals, or squared residuals, falls inside of the $5 \%$ critical lines and that in the linear function, money demand is relatively unstable as some of the cumulative sum of the recursive residuals, or squared residuals, fall outside of the $5 \%$ critical lines. In comparison, it appears that the log-linear function for the demand for M2 is better than the linear function in the stability test.

The expected inflation rate was considered in estimating the demand for M2. The coefficient is negative and insignificant. Thus, it is dropped from the final estimated regression. A possible reason of the insignificant coefficient is because the monetary aggregate is divided by the CPI and measured in real terms. Hence, a change in the price level has been included in the specification of the money demand function.

To make a comparison, the demand for M1 is estimated. The loglikelihood test based on the Box-Cox transformation shows that the loglinear form and the linear form can be rejected at the $5 \%$ level. In the general functional form, the coefficient of the real effective exchange rate is negative and significant at the $1 \%$ level, and the coefficient of the foreign interest rate is positive and insignificant even at the $10 \%$ level. M1 demand is positively associated with real output and negatively affected by the deposit rate and the real effective exchange rate. The CUSUM test shows the stability in the parameters while the CUSUMSQ test indicates the instability in the parameters. The mean absolute percent error of 5.050 is greater than 
that in the demand for M2. To save space, these results are not presented here.

\section{Summary and Conclusions}

This study has examined the demand for money for Pakistan. The extended Box-Cox transformation is applied to test whether the log-linear form and the linear form are appropriate. The Newey-West method is employed in empirical work to yield consistent estimates when the forms of autocorrelation and heteroskedasticity are unknown. The sample runs from 1980 to 2005 . For M2 demand, the analysis shows that the widely used loglinear form cannot be rejected while the linear form can be rejected. Based on the mean absolute percent error, the log-linear form for M2 demand performs better the linear form in forecasting. The demand for M2 has a positive relationship with real output and currency appreciation and a negative relationship with the call money rate and the foreign interest rates. Hence, when the exchange rate appreciates or depreciates, the substitution effect dominates the wealth effect. When the foreign interest rate rises, investors tend to reduce the holding of M2. In comparison, the demand for M2 is a better monetary aggregate than the demand for M1 in terms of the functional form, stability of the parameters, and forecasting errors.

There may be areas for further research. The Box-Cox model can be further extended to include different transformation parameters for the dependent variable and the explanatory variables. Quarterly data may be considered if manufacturing production can be used as a proxy for economic activity. The money market equilibrium may interact with the goods market equilibrium to determine the equilibrium values for real output and the interest rate. Also, the expected inflation rate could be constructed using other methods. 
Figure 1. CUSUM and CUSUMSQ Tests for M2 Demand

CUSUM Test for M2 Demand:

Log-Linear Function

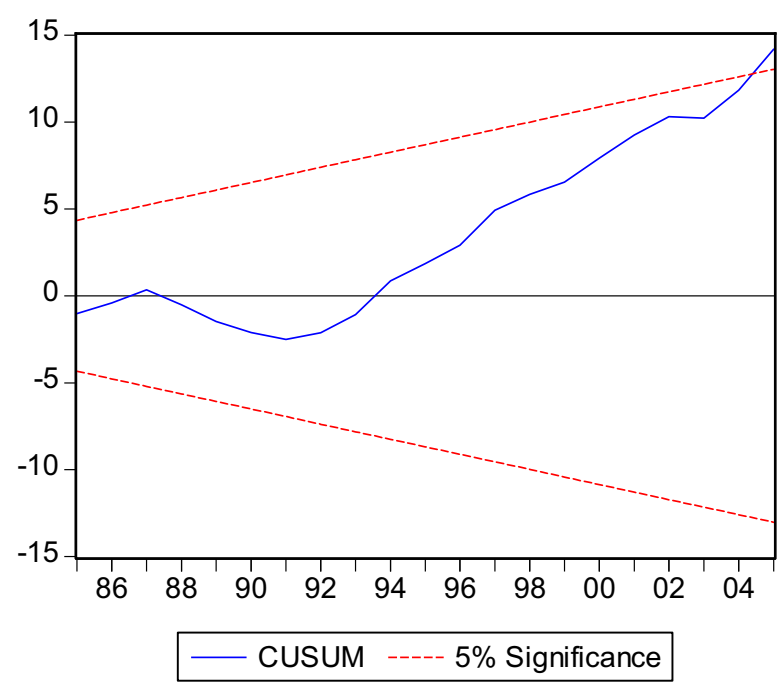

CUSUMSQ Test for M2 Demand:

Log-Linear Function

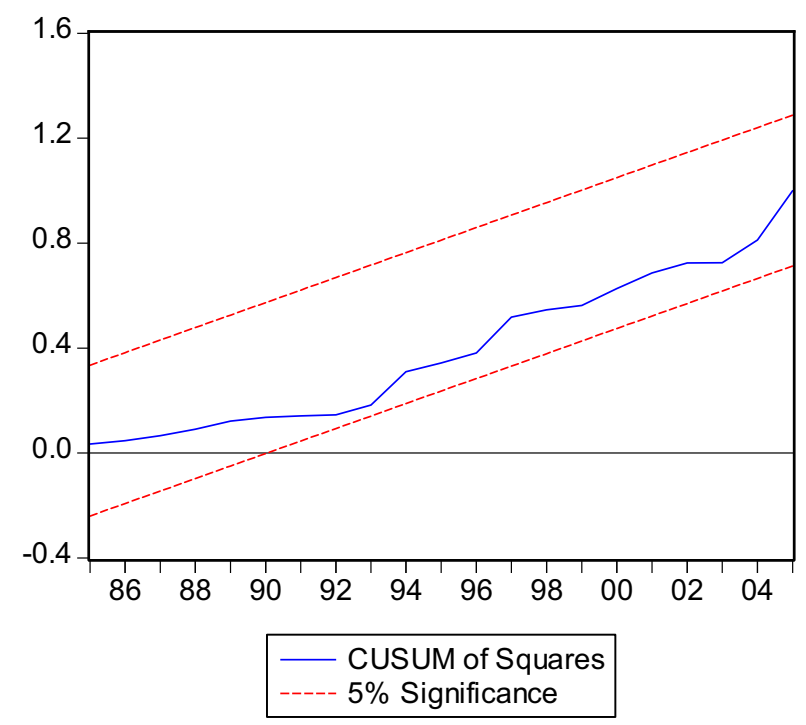


CUSUM Test for M2 Demand:

Linear Function

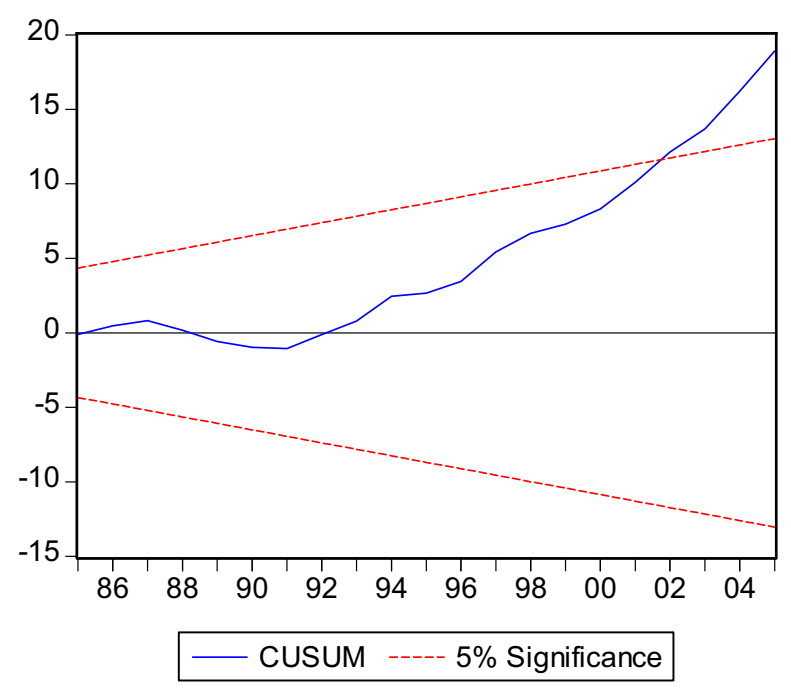

CUSUMSQ Test for M2 Demand: Linear Function

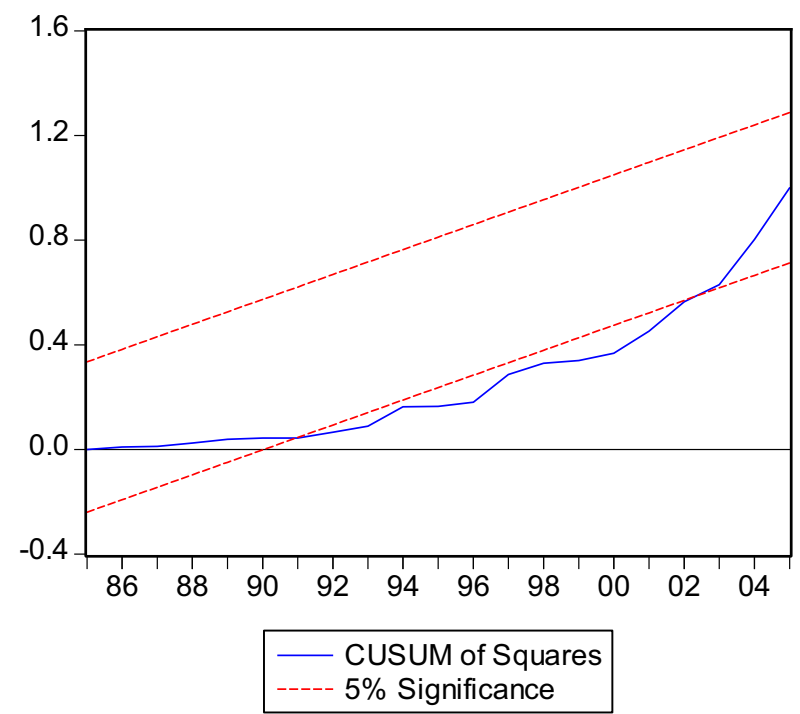




\section{References}

Arango, S. and M. I. Nadiri, 1981, Demand for Money in Open Economies. Journal of Monetary Economics, 7, 69-83.

Arize, A. C., 1994, A Re-examination of the Demand for Money in Small Developing Economies, Applied Economics, 26, 217-228.

Bahmani-Oskooee, M. and M. Malixi, 1991, Exchange Rate Sensitivity of the Demand for Money in Developing Countries. Applied Economics, $23,1377-1384$.

Bahmani-Oskooee, M. and A. Techaratanachai, 2001, Currency Substitution in Thailand. Journal of Policy Modeling, 23, 141-1.45

Bahmani-Oskooee, M. and S. Chomsisengphet, 2002, Stability of M2 Money Demand Function in Industrial Countries. Applied Economics, 34, 2075-2083.

Bahmani-Oskooee, M. and R. C. W. Ng, 2002, Long-run Demand for Money in Hong Kong: an Application of the ARDL Model. International Journal of Business and Economics, 1, 147-155.

Bahmani-Oskooee, M. and H. Rehman, 2005, Stability of the Money Demand Function in Asian Developing Countries. Applied Economics, 37, 773-792.

Box, G. E. P. and D. R. Cox, 1964, An Analysis of Transformation. Journal of Royal Statistical Society, 26, 211-243.

Carlson, J. B., D. L. Hoffman, B. D. Keen, and R. H. Rasche, 2000, Results of a Study of the Stability of Cointegrating Relations comprised of Broad Monetary Aggregate. Journal of Monetary Economics, 46, 345-83.

Choudhry, T., 1995, High Inflation Rates and the Long-run Money Demand Function: Evidence from Cointegration Tests. Journal of Macroeconomics, 17, 77-91.

Chow, G. C., 1966, On the Long-run and Short-run Demand for Money. Journal of Political Economy, 74, 111-31. 
Duca, J. V., 2000, Financial Technology Shocks and the Case of the Missing M2. Journal of Money, Credit, and Banking, 32, Part 1, 820-39.

Fair, R. C., 1987, International Evidence on the Demand for Money. Review of Economics and Statistics, 69, 473-80.

Fase, M. M. G. and C. C. A. Winder, 1998, Wealth and the Demand for Money in the European Union. Empirical Economics, 23, 507-24.

Friedman, M., 1988, Money and the Stock Market. Journal of Political Economy, 96, 221-245.

Goldfeld, S. M., 1973, The Demand for Money Revisited. Brookings Papers on Economic Activity, 3, 577-638.

Goldfeld, S. M., 1976, The Case of the Missing Money. Brookings Papers on Economic Activity, 3, 683-730.

Goldfeld, S. and D. Siche1, 1990, The Demand for Money. in Handbook of Monetary Economics, by B. M. Friedman and F. H. Hahn, Eds., Volume 1, North-Holland, Amsterdam.

Gordon, R. J., 1984, The Short-run Demand for Money: A Reconsideration. Journal of Money, Credit, and Banking, 16, Part 1, 403-434.

Greene, W. H., 2003, Econometric Analysis. Fifth edition, Prentice Hall, Upper Saddle River, NJ.

Hafer, R. W. and D. W. Jansen, 1991, The Demand for Money in the United States: Evidence from Cointegration Tests. Journal of Money, Credit, and Banking, 23, 155-168.

Hetze1, R. L. and Y. P. Mehra, 1989, The Behavior of Money Demand in the 1980s. Journal of Money, Credit, and Banking, 21, 455-463.

Hsing, Y., 1998, Tests of Changes in the Elasticity of the Demand for M2 and Policy Implications: the Case of Four Asian Countries, Journal of Economic Development, 23, 181-189.

Khan, M. A., Arby, M. F., and Lodhi, M. A. K., 2000, Disaggregated Approach for Modeling Demand for Money in Pakistan, Pakistan Journal of Applied Economics, 16, 65-77. 
Judd, J. L. and Scadding, J. L., 1982, The Search for a Stable Money Demand Function: a Survey of the Post-1973 Literature. Journal of Economic Literature, 20, 93-1023.

Laidler, D., 1990, The Demand for Money: Theories, Evidence, and Problems. $3^{\text {rd }}$ edition, HarperCollins, New York.

Marquez, J., 1987, Money Demand in Open Economies: a Currency Substitution Model for Venezuela. Journal of International Money and Finance, 6, 167-178.

McKinnon, R., 1982, Currency Substitution and Instability in the World Dollar Standard. American Economic Review, 72, 320-333.

Mehra, Y. P., 1993, The Stability of the M2 Demand Function: Evidence from an Error-Correction Mode1. Journal of Money, Credit, and Banking, 25, 455-60.

Mehra, Y. P., 1997, A Review of the Recent Behavior of M2 Demand. Federal Reserve Bank of Richmond Economic Quarterly, 83, 27-43.

Newey, W. K. and K. D. West, 1987, A Simple, Positive Semi-definite, Heteroskedasticity and Autocorrelation Consistent Covariance Matrix, Econometrica, 55, 703-708.

Phylaktis, K. and M. P. Taylor, 1993, Money Demand, the Cagan Model and the Inflation Tax: some Latin American Evidence. Review of Economics and Statistics, 75, 32-37.

Romer, D., 2006, Advanced Macroeconomics. Third edition, McGraw-Hill, New York.

Sarno, L., M. P. Taylor, and D. A. Pee1, 2003, Nonlinear Equilibrium Correction in U.S. Real Money Balances, 1869-1997. Journal of Money, Credit, and Banking, 35, 787-799.

Seaks, T. G. and S. K. Layson, 1983, Box-Cox Estimation with Standard Econometric Problems, Review of Economics and Statistics, 65, 160-164.

Small, D. H. and R. D. Porter, 1989, Understanding the Behavior of M2 and V2. Federal Reserve Bulletin, 75, 244-254. 
Taylor, M. P., 1991, The Hyperinflation Model of Money Demand Revisited. Journal of Money, Credit \& Banking, Part 1, 23, 327-351.

Tobin, J., 1958, Liquidity Preference as Behavior toward Risk. Review of Economic Studies, 25, 65-86. 